\title{
Liminality and the Diplomacy of the British Overseas Territories: An Assemblage
}

\section{$\underline{\text { Approach }}$}

\begin{abstract}
This paper examines diplomatic processes that compose our geopolitical world as dynamic and yet also seemingly affirm the status quo. It turns attention to the entrepreneurial creativity of individual diplomats, the transformations occurring at threshold moments, spaces and practices, and the materiality of diplomacy that exceeds human agency. The paper does so by forging an innovative dialogue between assemblage theory and the notion of liminality as developed in cultural anthropology, and by focusing on a hitherto overlooked set of diplomatic actors: British Overseas Territories (OTs). Three vignettes of OT diplomacy are traced: an account of the liminal subjectivity of London-based OT representatives; the 1982 Argentinian invasion that tipped the Falkland Islands into a state of greater autonomy; and the geophysical 'tipping point' of the 1997 volcanic eruption on Montserrat that made the island dependent for the foreseeable future. The paper concludes by noting potential avenues of future research that the synergy between liminality and assemblage may open up in the fields of Science and Technology Studies (STS), anthropology and geography.
\end{abstract}




\section{Introduction}

With the rise - and seeming decline - of Islamic State/Daesh, sub-state regions agitating for statehood in Europe, China (re)flexing its imperial muscles through the 'One Belt One Road' initiative and the galvanising of a global movement of indigenous peoples reasserting their right to self-determination we are seeing an increasing prominence of polities on the cusp of change that have the potential to shift from one state to another, without ruling out a shift back again. This paper focuses precisely on the notion of tipping points and its relation to polities being multiplicities: of existing in different states simultaneously.

If polities are multiplicities, then the interactions between polities - their diplomacy - is also multiplicitous. There has been increasing recognition by both practitioners and scholars that diplomacy, understood here as a combination of representation, communication and negotiation by and between polities, is undergoing rapid change. These changes include the emergence of new diplomatic actors, the transformation of diplomatic practices through new technology (Bjola and Holmes 2015) and the increasingly blurred professional lines between diplomacy and spheres such as the military, humanitarian aid, and environmental science (Hocking et al. 2012). There has been a parallel diversification in the theoretical and methodological approaches to studying diplomacy, with a growing body of research challenging the idea of diplomacy as the special preserve of the state (e.g. Constantinou and Der Derian 
2010; Dittmer and McConnell 2016). Scholars in critical international relations (IR) and geography have drawn on poststructuralist perspectives to explore the role of discourse in diplomacy (Der Derian 1987; Constantinou 1996), have been inspired by the 'practice turn' to examine the everyday habits and mundane performances of diplomats themselves (Neumann 2002; Kuus 2014; Jones and Clark 2015), and have interrogated the relationship between 'old' and 'new' diplomacy (Sending et al 2011). These approaches have resonances with shifts in state theory that attend to how states are themselves effects produced through discourse and performance (Weber 1998; Jeffrey 2013; McConnell 2016) and posit that diplomacy is productive of geopolitical space. Drawing on different theoretical emphases, but arriving at a similar place, Dittmer $(2015$; 2016) adopts a Deleuzean approach to diplomacy, emphasising the affective potentials within diplomatic encounters. In conceptualizing states as assemblages, diplomatic encounters become understandable as second order assemblages bringing state bodies, materials, and objects into relation with one another in ways that establish new affective vectors and open up new potentials. States engage in diplomatic relations to extend their own power in space, but in doing so they open themselves up to diplomacy's constitutive power, which actively reworks the state assemblage. Therefore states should not be conceptualized as stable entities engaging in diplomatic practices, rather states and the larger assemblages that they form with one 
another must be understood as in a state of becoming-together, with new potentials for political change inherent to this dynamism.

In this paper we seek to push this innovative understanding of diplomacy as dynamic and contingent further by turning attention to the entrepreneurial creativity of individual diplomats, the transformations occurring at threshold moments, spaces and practice, and the materiality of diplomacy which exceeds human agency. We do so by both forging a dialogue between assemblage theory and the notion of liminality as developed in cultural anthropology, and by focusing on a hitherto overlooked set of diplomatic actors: British Overseas Territories (OTs).

British OTs are territories under the jurisdiction and sovereignty of the United Kingdom but are constitutionally not part of the UK: each territory has a separate constitution and a unique legal relationship to the UK. Since 2002, all inhabitants of British OTs have full British citizenship ${ }^{1}$ and the inhabited OTs have Governors that are appointed by Queen Elizabeth II and are de facto heads of state. Formally, OTs have no competency for foreign policy; even as more governmental functions have been delegated to their locally elected legislatures, the Foreign and Commonwealth Office (FCO) remains the conduit for their diplomatic relations. Nevertheless, in practice these polities engage in many forms of diplomacy: with London, with each other, and with other polities (e.g. neighbouring states and regional organisations). We hypothesize that

\footnotetext{
${ }^{1}$ The exception is individuals connected solely with the Sovereign Base Areas in Cyprus.
} 
this seeming paradox can be understood through an examination of OTs' diplomatic practices using the conceptual lenses of liminality and assemblage.

The British OTs, we posit, are an excellent example of liminality, in that they perform differently in different times and spaces. This dynamism is not accounted for in theories of IR that view states (and OTs) as static categories rather than as multiplicities. If liminality points to the spaces and times that are politically fertile, the concept of assemblage enables us to study the material conditions in which these time-spaces of creativity emerge. The scientific roots of assemblage theory are replete with terms such as tipping points, events and territorialisation - that have thus far not been connected with the anthropological literature on liminality despite their significant resonances. Our synthesis of these literatures will provide a potent theoretical lens through which to examine the British OTs, and will potentially have wider applicability.

We first review the conceptual history of liminality before attending to the way in which we might theorize liminality through assemblage. We lay this conceptual framework alongside a discussion of the dynamic historical relation between the UK Government and the British OTs. We then substantiate our conceptual claims by tracing three vignettes. These are based on interviews with London-based OT representatives that highlighted the liminal position of these individuals within the metropole and gestured towards the dynamism, contingency and creativity of OT diplomacy more generally. We pursued the latter in relation to specific OTs with analysis of policy 
documents related to key diplomatic events. We acknowledge that these vignettes lack the empirical depth and thick description that would normally be necessary to maximize the insights gained into geopolitical assemblages, but our approach allows for snapshots of these assemblages over time to be productively juxtaposed, enabling comparative insights to form. The first vignette is an account of the recent history of London-based representatives of the OTs, whose position and practices broadly substantiates our claim that these are liminal actors. We then trace the multiplicity of diplomatic relations that have existed between the Falkland Islands and the British Government and between Montserrat and the British Government over time. These two relations are notable because of the role of events in re-configuring those relations and the OTs themselves. For the Falkland Islands, the 1982 Argentinian invasion was an event that tipped the Falklands into a state of greater autonomy, while for Montserrat the 1997 volcano eruption had the opposite effect, making the island dependent for the foreseeable future. These vignettes collectively demonstrate both how liminality is a characteristic of the OTs, and how assemblage theory directs our attention to the specific energies and materials that enable shifts in polities' multiplicitous forms. We conclude by noting the potential avenues of future research that the synergy between liminality and assemblage may open up in the fields of Science and Technology Studies (STS), anthropology and geography. 


\section{Bringing liminality and assemblage into dialogue}

It is well-established that marginal actors, spaces and conditions are productive foci for analysis, providing important cases of resistance and radical possibility (Soja 1996; Sharp 2013) and offering insights into the power relations that underlie the 'core' (Navaro Yashin 2003). Despite this, liminality has been largely overlooked in academic geography (see McConnell 2017). This is surprising both because of the spatial dynamics underpinning liminality, and its revival in other social science fields. Contemporary scholars in, inter alia, conflict studies, literature, education, business studies and sociology have used liminality to discuss cases as diverse as airports and hotels, transgender identities and natural disasters. Indeed Thomassen (2015: 39) goes as far as to assert that, given its utility for understanding phenomena in the contemporary era characterised by 'constant change, uncertainty and institutionalized contingency,' liminality 'should be considered a master concept in the wider social and political sciences'.

Liminality has its roots in the Latin limen, meaning a threshold that needs to be crossed. Arnold van Gennep first explored the concept in his seminal Rites of Passage (1909). The term gained wider traction when cultural anthropologist Victor Turner developed van Gennep's framework in the 1960s. Paying particular attention to individuals who undergo liminal experiences, Turner analysed liminality as a condition 'betwixt and between the positions assigned and arrayed by law, custom, convention 
and ceremonial' (1969: 95). Turner's understanding of liminality has been extended beyond the cultural sphere and the scale of individuals. Scholars in political science and IR have used liminality as a paradigm for understanding societal-level crisis situations, structural transformations of institutionalised orders and the constitution of political identities (e.g. Norton 1988; Horvath et al 2015). This has included research on peripheral states that fit neither the categories of 'self' nor 'other' in narratives of European identity (Rumelili 2003; Yanık 2011), the liminality of post-communist transitions (Horvath 2009) and conceptual work disrupting the essentialized binary of domestic/international (Mälksoo 2012).

There is further potential for the application of liminality across a range of problems in international politics, and it is a concept that has productive intersections with political geography (McConnell 2017). First, with its roots in experiential dimensions of social change, liminality facilitates a more dynamic conceptualisation of political subjectivity. By emphasising boundary zones and thresholds, liminality disrupts traditional categorisations of geopolitical actors as states or non-states, and provides insights into the contingency of belonging and recognition. The resultant emphasis on the processual nature of international life, the relationality of power, and the dynamic temporality of international politics (Mälksoo 2012) offers a nuanced understanding of transformation, emergence and becoming within the international system. This foregrounding of the polyvocality of political subjectivity and the 
eschewing of hierarchical orders, binary oppositions, and teleological implications also has important resonances with recent work that rethinks the nature of political legitimacy. As scholars in a recent special issue of Geoforum (Vol 66 November 2015) have argued, when the assumption that the state is the sole arbiter and provider of legitimacy within a territory is unsettled and legitimacy is de-linked from its traditional association with legality and recognition, then this concept emerges as 'a processual technique of governance rather than an achieved status' (Jeffrey et al 2015: 180). Read in this dynamic and plural way, a range of polities - state and non-state, recognised and unrecognised - can be seen to claim and contest legitimacy. In turn, having legitimacy acknowledged can mark the emergence of a polity from one status, being tipped into another.

Second, just as legitimacy is a productively ambiguous concept (ibid.), so too is liminality. As a 'transition during which the normal limits to thought, selfunderstanding and behaviour are relaxed' (Thomassen 2014: 1) liminality enables intense creativity and thereby shines a light on practices of innovation, political renewal and imagination. Yet, contra Turner, such creativity does not mean that liminality automatically has emancipatory qualities. Rather, liminality is an inherently ambivalent condition: 'the stimulation of creative potentials is inseparable from tragic experiences' (Szakolczai 2015: 34). In sum, there is consensus in the literature that liminality is a state in which a person, place, or thing is unsettled, teetering on a threshold with micro- 
scaled dynamics threatening to tip them/it into a different state of being. Beyond this, the largely anthropocentric literature on liminality has little to say on the specific material conditions that produce these dynamics. We propose, first, that liminality has distinct resonances with the notion of assemblage and, second, that assemblage theory provides a conceptual toolbox through which specific cases of liminality can be analysed.

Assemblage theory emerged from the work of, inter alia, Deleuze and Guattari (2001) and DeLanda (2006), and has parallels with actor-network theory (e.g., Latour 2005; Callon 1986). It is an approach that, like work on liminality, brings questions of emergence and becoming to the fore and encourages an openness to the potentiality of change over time, but is distinct in its focus on a more-than-human perspective. Assemblages are 'wholes characterized by relations of exteriority,' (DeLanda, 2006: 10, emphasis in original). Therefore material elements in an assemblage are not limited to their roles in that assemblage, as they may simultaneously be in other assemblages (Anderson and McFarlane 2011). For instance, a diplomat's performance does not just contribute to the becoming of one assemblage (e.g., a diplomatic encounter), but simultaneously contributes to the becoming of another (e.g., the state); both assemblages have that diplomat in common. Therefore, affects originating in one assemblage can ripple through 'neighbouring' assemblages sharing common elements (Dittmer 2014). Further, assemblage approaches emphasise the role of non-human 
elements in the emergence of human subjectivity and agency. For instance, a diplomat's agency is not pre-existing but is emergent from both their bodily capacities and the tools and technologies with which that body is in assemblage. Larger apparatuses such as the state and the international political system are composed by similar processes (Legg 2009). This becoming-together of foreign policy elites and their states has profound impacts on both the micro-practices of foreign policy formation and on macro-scaled international affairs that are only now being explored empirically (Dittmer 2015; 2016).

Even as they are dynamic at a range of spatial and temporal scales, assemblages often appear stable. This is because each assemblage is a multiplicity of forms, only one of which is actualized in a given space/time. The others remain virtual, that is they are possibilities within the material constraints of the system that are not (yet) actualized. DeLanda (2006) visualises this multiplicity of forms in an abstract mathematical space, with various possibilities plotted in a multidimensional grid. In doing so it becomes possible to chart the tendencies of the assemblage, which are mapped as a basin in which most actualizations cluster around one or more 'attractors', or ideal forms. Outliers are actualizations that resemble the ideal form less and less, until they become closer to another attractor in this multidimensional space and tip into a different basin of attraction. For this reason, increasing intensities will seem to have little effect on an assemblage until suddenly it reaches a 'tipping point' and the elements 
re-territorialize in a new form, unleashing energies that can ripple through neighbouring assemblages sharing common elements.

The notion of tipping points has resonances with recent work in human geography that calls attention to the event as a crucial element of the political. For instance, in asking 'how do we theorize and represent events and the worlds that they transform?' Shaw (2012: 613) directs our attention to the raw non-human forces that act upon our human politics, the contingency with which this politics unfolds and, conversely, the systemic stability that usually reigns (until it doesn't). Diplomacy is a field that would seemingly be well-positioned to examine 'the event', given how it has often been understood to hinge on events: summits, state dinners, 'accidental' encounters in the hallways at the United Nations.

Drawing from the outline of assemblages above, we conceptualize the event as the result of intensive processes that push an assemblage across a tipping point, transforming the materials, bodies, and energies found within a given assemblage and potentially altering neighbouring assemblages. Events are often imagined as grandiose, epochal things, but this ignores the range of spatial scales and temporalities in which assemblages unfold. Adopting a Deleuzean approach, Ingram (2017) conceptualises the event as potentially less dramatic than 'the transformation of worlds'; rather, he notes that events happen all the time, often beneath our notice or with less-than-worldtransforming consequences. In the remainder of the paper, we use the conceptual 
language of assemblage theory - events, tipping points, actualization, territorializationto examine how an entity - in this case a British Overseas Territory - might have a material configuration that is liminal, i.e., existing at the edge of one configuration and therefore on the precipice of rapid transformation. We thereby explore emergent events - both obvious and subtle - that have shaped the political forms and diplomatic capacities of the British OTs.

This fusion of assemblage and liminality is productive for several reasons. First, it makes clear the multiplicity of every polity (OT or otherwise), thereby demolishing the hard-and-fast definitions of 'the state' and other categorical framings of political life. It instead shows the flexibility of polities, and their ability to actualize various forms under different conditions. Second, our synergy of assemblage and liminality provides an epistemological and ontological framework through which those different forms and conditions can be explicated. As our case studies demonstrate, this framework points to different sites within the assemblage as being power-full at crucial moments during transitions. Third, the strength of the assemblage approach to liminality is in the way that it builds on the relational approaches that have become ascendant within critical diplomacy studies while not perpetuating the state-centrism that has dominated the wider field. For example, Sending et al. (2011, p.529) have described the treatment of proliferating diplomatic actors in the literature as 'explanation by naming'. Our framing of assemblage-liminality pushes beyond this classificatory approach by empirically 
examining and conceptually reimagining how diplomatic capabilities emerge (or don't) from specific arrangements of materials, bodies and territories.

\section{Shifting relations between the British Government and its Overseas Territories}

Scattered across the world are a series of polities - mostly small islands - which are remnants of European empires and which have thus far rejected independence in favour of retaining links with their former imperial powers (Aldrich and Connell 1998; AdlerNissen and Gad 2013). The UN categorises seventeen of these polities as 'Non-SelfGoverning Territories' (NSGTs) and is determined to see through the decolonization process (which need not mean independence) through dialogue amongst the administering powers, the peoples of the territories, and the Special Committee on Decolonization. Ten of the seventeen NSGTs are British OTs: Anguilla, Bermuda, British Virgin Islands, Cayman Islands, Falkland Islands, Gibraltar, Montserrat, Pitcairn Islands, Saint Helena, Turks and Caicos Islands.

The " "pandora's box" of what to do to decolonise relationships with some of the last, and longest lasting, remnants of Empire' (Clegg 2009: 8) has long bedevilled the British Government. From the 1970s until the late 1990s the British Government assumed that the then-termed 'Dependent Territories' would become independent in time and it would therefore be able to "wash its hands of these "leftovers of Empire" (Hintjens and Hodge 2012: 198). As a result, relations between Whitehall and the 
Dependent Territories were ad hoc, and little different from the compromises and arbitrary settlements that characterised colonial administration (ibid.). However, with popular demands for independence in the Territories failing to materialise, the policy stance of waiting for an inevitable transfer of sovereignty and thereby completion of decolonisation became increasingly untenable.

It took two significant events in the Territories to shock the FCO governance structure into a new form: the devastating volcanic eruption on Montserrat in 1997 (discussed below) and the corruption scandal that gripped the Turks and Caicos Islands (TCI) in 2009. These 'threshold situations' - one natural, one man-made - brought into stark relief the British Government's contingent liability vis-à-vis the Territories and prompted it to act upon its responsibilities. This shift in the relationship between the British Government and the Territories was solidified through two White Papers: 'Partnerships for Progress and Prosperity' issued by the Labour government in 1999 and 'Security, Success and Sustainability' issued by the Coalition government in 2012. These Papers document significant political renewal in the relationship between the British Government and its Territories, and an acceptance of 'shared post-colonial responsibilities' based on the principle of partnership (Hintjens and Hodge 2012: 192; Clegg 2013). This paradigm shift was both symbolic in the renaming of 'Dependent Territories' as 'Overseas Territories' and material in a series of new institutional arrangements (described below). 
Thus, while encouraging the drafting of new constitutions in many of the OTs, the UK has forged a more assertive role to safeguard its interests. This has meant that the OTs remain on the UN list of NSGTs, but it has nevertheless been in both sides' interests for the OTs to maintain a liminal political subjectivity between colonial ward and independent statehood. One area of ambiguity is international affairs. The 2012 White Paper states that 'The UK Government is responsible for the external relations of the Territories but we encourage Territory Governments to play an active role in building productive links with the wider world' (FCO 2012: 79). This devolution of powers for external affairs makes sense both as a means of freeing up FCO resources during a time of intense budgetary pressure, and as a means of promoting more resilient, entrepreneurial economies in the OTs, which can relieve the UK of potential financial liabilities. Further, devolving power strengthens the argument that the OTs are selfgoverning and therefore not colonies, a charge that has been used by Spain and Argentina in their disputes over Gibraltar and the Falklands (respectively). As such, whilst the OTs may be deemed illegitimate in the eyes of some within the international community, particularly as a result of their remaining on the list of NSGTs, they are simultaneously presented by the UK Government, and seek to self-represent, as legitimate polities that adhere to core principles of international good governance. OTs are thus sites of contestation where legitimacy is in emergence. 
Despite these intriguing characteristics, the diplomacy of OTs has attracted surprisingly little academic attention, including from scholars who have focused on the opportunistic and experimental diplomacy of sub-national governments, known as paradiplomacy (see Cornago 2010; Keating 1999). What scholarship there is on OTs has predominantly been either detailed case studies of particular OTs or comparative analyses. The former includes research on Caribbean offshore financial centres (e.g. Hudson 1998), imperial discourses in Gibraltar (Lambert 2005), the role of OTs in South Atlantic geopolitics (Dodds 2016) and citizen statecraft in the Falklands (Pinkerton and Benwell 2014). Comparative analysis has emerged from political science and has focused on issues around constitutional reforms (e.g. Clegg and Gold 2011; Clegg and Killingray 2012; Clegg 2013; Hintjens and Hodge 2012) or the attitudes of different European states to their overseas territories (e.g. Oostindie and Klinkers 2003). Of particular note is Adler-Nissen and Gad's edited volume on the 'sovereignty games' played between OTs, their former colonizer states and the EU: games which involve contradictory processes of fragmentation and integration. In what follows we both extend this work and forge a new approach to examining OTs. Our three vignettes do not constitute a comparative study per se, but neither is this an in depth examination of a single case. Rather, we bring insights from liminality and assemblage to bear on particular sites and events of British OT diplomacy in order foreground hitherto overlooked aspects of these distinctive polities: their dynamic, in-between status, the 
role of material objects and geophysical forces in shaping OT diplomacy and the transformations that occur at threshold moments.

\section{London representatives of the OTs}

Perhaps the most obvious place to observe OT diplomacy in action is in the metropole: London. The OTs have long had an official presence in London, but it is a presence defined by liminality. All but the Pitcairn Islands currently have an official representative in the city, and most OTs have offices in imposing buildings with soughtafter London addresses and all the accoutrements of official embassies: brass door plaques, flags, glossy photographs of the territories' flora and fauna, and oak-panelled meeting rooms. The representatives are appointed by their OT Government and, as was clearly articulated in the interviews, these individuals embody an ambiguous, inbetween political status. On the one hand they are definitively not recognised as diplomats under international law and they are not granted the privileges of diplomatic immunity under the Vienna Convention on Diplomatic Relations (1961). On the other hand, the British Government does recognise that they carry out diplomatic functions. There is official acknowledgement of their presence in the city, and in particular spaces and at particular times they are treated as de facto diplomats. They are, for example, invited to attend diplomatic events such as Commonwealth Day events and garden parties at Buckingham Palace. Given that they are otherwise on the fringes of the 
London diplomatic corps, these events provide important networking opportunities and a chance to assert the legitimacy not only of their diplomatic role but also of the OT Government they represent. The in-between status of the OT representatives is exemplified by the London Diplomatic List, ${ }^{2}$ a document that reinforces Caspersen's (2015) assertion that we should think of 'degrees of legitimacy.' The OTs appear as the penultimate entries, long after the list of official state embassies and consulates, below 'career consuls-general' (Agents-General for particular provinces of Australia and Canada) but above 'other representative offices and organisations in the United Kingdom', such as the Palestinian Mission to the UK.

This liminal position in London is also actively cultivated by the diplomats themselves, as it enables mobilities that other diplomatic actors do not have. As one representative noted, 'it's important to leave ambiguities intact... that is to our advantage as we can position ourselves with flexibility. We can foster relations with members of the diplomatic corps, but also lobby MPs or negotiate with DfID [Department for International Development]' (interview, August 2015). The representatives thereby present themselves as existing in multiple states at once: as an independent diplomatic actor, as part of the UK, and as politically subordinate to the UK. This allows diplomatic creativity and entrepreneurship as, freed from the

\footnotetext{
${ }^{2}$ A list of the representatives of Foreign States and Commonwealth Countries in London published monthly by the FCO.
} 
constraints that accompany membership of the official diplomatic corps, OT representatives are able to experiment with different modes of diplomatic practice (see Dickson 2014).

There is, moreover, a contingency to this liminal subjectivity, and it is only in the past decade or so that the London representatives have been able to cultivate this advantageous in-between position. As one representative recounted to us, of the hefty handover documents he received thirty years ago, most of it [he gestured to the thickness of the files] was predominantly a list of things not to do. At that stage the most significant objector to the establishment of the London offices of the OTs was the FCO itself, which saw them as potential trouble-makers. Those barriers have slowly broken down and today the representatives are increasingly recognised and valued for their work, including acting as sounding posts for the introduction of new legislation by the British Government. Crucial to such a role is having both a physical presence in the city and the personal relationships built up between OT and British Government representatives. This points both to the contingency of legitimacy and to the material dimensions of the diplomatic assemblage.

The policy changes since the late 1990s have seen a regularisation of the relationship between the OTs and the British Government through shifts in the apparatuses involved. The ad hoc oversight of the Territories, with responsibilities dispersed over different regional desks in the FCO, was replaced by a single, dedicated 
OTs Department, the appointment of a minister for the Territories and the establishment of a new political forum, the Joint Ministerial Council (Clegg 2013). The latter brings the OTs' elected representatives together with central government representatives and enables the former to have direct input into decision-making (Hintjens and Hodge 2012). In short, the spaces and procedures of the FCO were re-coded to produce a more coordinated response to the OTs.

This re-coding of the FCO's OT apparatus affected, and was affected by, the establishment of an umbrella organisation for the OT representatives in London. Beginning in 1994 as a forum to bring together the Falkland Islands, Gibraltar and Cayman Islands, the UK Overseas Territories Association (UKOTA) has become a key space for coordination across the OTs. This includes pooling their limited resources, sharing information about British Government policies and presenting a joint voice on shared issues of concern, from environmental policy to human rights legislation and tax status. Viewing this through the conceptual lens of liminality, UKOTA emerges as an enabling site for communitas, an affective experience of equality that emerges through experiencing liminality together (Turner 1974). Despite their political differences strong bonds are forged between the OTs through this institutionalised setting: in the creation of community there is mutual becoming and belonging. Therefore what we see beginning in the 1990s is a mutual becoming through which the FCO apparatus and those of the OTs centralized their relations, both within and without. 
Despite these processes of mutual centralisation, there is simultaneous fragmentation on both sides. Responsibility for the OTs now extends well beyond the FCO, to other government departments as well as local government, private companies and NGOs (Clegg 2013). Meanwhile, as our interviews revealed, amongst the OTs there remain stark differences. Each OT is governed in its own way and each has a distinct, dynamic relationship with the UK. For instance, the Falkland Islands and St Helena currently fully support the status quo, while Bermuda and Anguilla are keen to explore options for further autonomy. The desire and capability for political autonomy (if not independence) is thus unevenly distributed across the OTs, and it is not entirely a product of political entrepreneurship. Rather, political autonomy is emergent from the intersection of a range of material forces (Protevi 2009), only some of which are human and subject to a reflexive intentionality.

It is the dynamism of these relationships that our approach highlights. In this vignette we have shown that the OT representatives have fostered their liminality in London, using the mobilities and materialities at their disposal to maximize their influence. Assemblage theory also provides a conceptual language for considering the mutual becoming of the FCO bureaucracy and the OTs' relations with one another. Whereas the previous literature on the OTs has emphasized the constitutional relations between the OTs and the UK, our approach allows us to think about that relationship alongside the relationship between the OTs, such as through UKOTA. In the next two 
sections we examine the unfolding of processes of assemblage in the Falkland Islands and in Montserrat, tracing the material constellation of things, bodies, and objects as they confront an event - an influx of material energies - and subsequently reach tipping points.

\section{Tipping Point 1: 1982 and the Falkland Islands}

In what follows we articulate the narrative of the Falkland Islands as a transition from British political dependency to near-autonomy. While this transition was ongoing over a long period of time, a rapid shift was sparked by the events of 1982 as the political apparatus of the Falklands interacted with other assemblages, such as the UN and the Argentinian military apparatus. Here our assemblage approach enables us to highlight various events - the 1982 invasion, the 2013 Referendum, the annual meeting of the UN Special Committee on Decolonization - as material-energetic transformations that are productive of various forms of legitimacy and belonging. In the existing literature on the Falklands, these events tend to be considered as coming from distinctly different fields of political practice - military practice, democratic practice, and diplomatic practice. Assemblage thought allows us to consider all three events as part of the same open whole, with each a coming together of bodies, materials, and energies to affectively re-code the polity. 
From the 1830s through World War II, the apparatus governing the Falkland Islands was London-based. The Colonial Office appointed the Governor, who in turn controlled the Falkland Islands Government, including appointing the legislative council. By the late 1940s, however, the Foreign Office and Colonial Office were aware that anti-colonial pressure was increasing and the lack of self-government in the Falklands Islands could be used against the UK in international forums such as the new UN. In response, universal suffrage was introduced in the Falkland Islands Order of 1948 and the first election of Legislative Council members (four out of twelve were directly elected) was held a year later (Dodds 2002).

This constitutional system - a hybrid of colonial and democratic regimes - was broadly acceptable to the population of the Falklands, but came under pressure as a result of the re-territorialization of the UK's foreign policy apparatus, which culminated in 1968. When the Colonial Office and Commonwealth Office were folded into the Foreign Office, creating today’s FCO, inward-looking questions of democratic accountability and good governance became reframed as outward-looking foreign policy matters. Meanwhile the Argentinean claims to the Falkland Islands were framed at this time through questions of territorial, rather than popular, sovereignty (see Benwell and Dodds 2011; Keeling 2013). The FCO itself hoped that the Islanders might become more open to Argentina with time, eventually enabling a resolution to the dispute. Yet during this period the Falkland Islanders increasingly portrayed 
themselves as a 'loyal colony' (Dodds 2002: 131) to British audiences, in hopes of forestalling a deal by the FCO with the Argentineans on Falklands sovereignty.

The 1982 invasion marked a tipping point in the Falklands apparatus. First, the war cemented the relationship between British nationalism and the UK's small territory in the South Atlantic. It was no longer necessary for the Islanders to argue for their Britishness: it was taken-for-granted, sealed in the blood of the British military. As Dodds notes, 'Thatcher [argued] that the formal sovereignty of the Falklands was nonnegotiable... [and] the 1982 British Nationality (Falkland Islands) Amendment Act was passed to enable all Falkland Islanders to become British citizens' (2002: 185). Second, a new constitution was promulgated in 1985, emphasizing self-government. In stating that all Falkland Islands Government Councillors would be directly elected the new constitution effectively reduced the political role of the London-appointed Governor (ibid). By sealing the political link between the UK and the Falklands, the invasion thus paradoxically re-shaped the Falklands into a more autonomous polity. Of course, manifesting this new postcolonial governmental apparatus in the realm of diplomacy requires the re-organizing of materials and bodies in space so as to render this new form visible. In this case, we examine two sites in which the new postcolonial Falkland Islands were materialised: the 2013 Referendum and the UN Special Committee on Decolonization. 
The Falkland Islands Government announced the referendum in June 2012, at the peak of the international commemoration of the $30^{\text {th }}$ anniversary of the Falklands Islands War. Held in March 2013, the referendum should be understood as an event, a coming together of bodies, technologies, and spaces that enable an object - the result to emerge in the political field and exert its agency (Page and Dittmer 2015). That this is a profoundly material event is clear from the account of the referendum given by Dodds and Pinkerton (2013). At its most basic level, the referendum relied on ballots, brought into relation with individual voters, such that they become marked with what is assumed to be voters' preferences. These ballots are then aggregated into a table to calculate something that might be understood via liberal political philosophy as 'the will of the people'. Notably, this event is therefore also (re)constitutive of this emergent category: 'the people'. This is crucial as the UK's claim to sovereignty over the islands is based on the self-determination of the islanders, whereas Argentina's claim is territorial in nature. Maximizing the voter turnout (which is understood as increasing a referendum's legitimacy) entailed the operation of four polling stations, a series of mobile teams to canvass the islands, and even an airplane-based polling station to serve the outer islands (ibid.). Beyond the bodies of the voters themselves, another set of bodies crucial to the referendum's significance were those of the international observers. Their importance is clear from the efforts undertaken by the Argentinian Government to thwart international participation. In the end, the Canadian Government funded the observation team, and 
the observers certified the referendum result ( $99.8 \%$ in favour of remaining an Overseas Territory) before the assembled global media. The international recognition of the referendum was a key performative dimension of the event's unfolding: the Falkland Islanders are a 'people', exercising their self-determination and acting in practice with relative autonomy.

Another site at which this relative autonomy is proffered to a global audience on an annual basis is the UN Special Committee on Decolonization. The Falkland Islands are a regular feature of this annual diplomatic event, as a 1965 General Assembly resolution called for peaceful resolution of the situation via negotiation. As the Special Committee is obliged to report on the progress towards this goal its meetings are flashpoints for contestation over the liminal nature of the Falkland Islands polity: is it a colonial dependency, or a near-autonomous polity?

The UK Representative of the Falkland Islands described to us how the task of representation has (informally) changed in recent years:

The lines of demarcation between the Overseas Territories and the FCO used to be quite rigid regarding representation overseas. This changed about five years ago for the Falklands. The UK Government thought it would be expedient for the Falkland Islanders to argue their own case. So the FCO launched a public diplomacy programme, including training and secondments... Now Falkland Islands Assembly members tour Latin America, Canada, the United States, 
etcetera, representing the interests of the Islands... and appearing at the C24 [Special Committee] (Interview, 2015)

As a highly routinized diplomatic site, the Special Committee is produced via the usual trappings of diplomacy and is a site where competing sources of legitimacy are articulated and embodied. The variable from year to year is found in the bodies dispatched to diplomatically represent the polities. For the Falkland Islands, these are two members of the Legislative Assembly, who generally speak about the relative development of the Islands and the will of Islanders to engage in self-determination. For instance, at the 2013 meeting, Sharon Halford of the Legislative Assembly highlighted the outcome of the referendum, and stressed that the Falkland Islands was hardly a British settler colony, but instead home to people of 57 different nationalities (in a population of roughly 2,500). Assembly member Michael Summers followed Halford by arguing that the Special Committee had no mandate to resolve sovereignty disputes and should instead uphold the Islanders' right to self-determination (Special Committee 13 June 2013). Together these diplomats personally embodied - via their roles as democratically elected members of the Government - an understanding of the Falkland Islands polity that is rooted in good governance, self-determination, and community: qualities that are proffered to legitimate the liminal polity in the eyes of international law. Notable by their absence in these meetings is any representative of the UK; having FCO bodies in the room would have undercut the claim of the Islanders to self- 
representation and self-determination, and compromised the claim of them to be legitimate representatives of the Islanders.

Argentina also dispatches representatives to the annual meeting and, through the biographies of these individuals seeks to legitimise its own claim to the islands. First among the representatives is usually the Foreign Minister (unless the President addresses the committee, as in 2012), who articulates a narrative of British colonial intransigence. In the 2013 meeting the Foreign Minister interpreted the aforementioned lack of British representation in the meeting as imperial hubris (Special Committee 20 June 2013). In 2015 Argentina had two Falkland Islanders speak on their behalf: Guillermo Clifton, a second-generation Islander who critiqued British oil exploration in the area and its environmental consequences, and Picardo Patterson, who complained of British intransigence in the face of Argentine generosity. These 'diplomats' and the narratives that they embody work to produce a set of claims on the territory of the Falklands; the bodies of the state (foreign minister, president) set the scene for the narratives of territorial loss offered up by the private petitioners: of homes lost, of ways of life destroyed, of British stonewalling in the face of near-global approbation. Here the 'decolonization' called for is not the 'postcolonial' Government found in Stanley, but the teleological eradication of colonialism originally envisioned in the UN after World War II. 
History shows that the 1982 invasion by Argentina accelerated the Falkland Islands' movement from one materialized formation into another, gaining the trappings of an independent polity without realizing that actual state. Nevertheless, it remains unable to satisfy its critics despite moving as far as possible in its current configuration. Were this OT to move any further towards autonomy it would have to become independent, and yet this would appear to be impossible because the Islands' autonomy is predicated on continued British military and diplomatic protection. Assemblage thinking allows us to understand this political liminality as a particular equilibrium of material flows; while there may be many other potential equilibria, it is unclear how the polity can move from one state to the other in the current context.

\section{Tipping Point 2: 1997 and Montserrat}

In this final example we turn to Montserrat, an OT that, in contrast to the Falklands experience, has tipped from a state of self-sufficiency into a form of colonial dependency. If in the last vignette our approach enabled us to consider 'legitimacy' as an emergent property of the Falklands assemblage, this vignette allows us to understand the 'viability' of a polity like Montserrat in similar terms, with material-energetic events both pushing the polity towards particular equilibria and re-shaping the political subjectivities of policy-makers and citizens. In this case, due to volcanic eruptions, the 
foreseeable future in Montserrat is sustained by significant flows of aid money from the UK budget, which codes the polity as 'unviable'.

Montserrat became a British dependency in 1632. Its history as an island of white-owned plantations dependent on imported slave labour meant that Montserrat originally had a (white) representative democracy; however the end of the slave trade brought closer oversight from London with Crown Colony status in the late 1800s (Skelton 2000). While this can be read as UK intervention to end slavery on the island, it can equally be read as the maintenance of white rule over a majority black population in a post-slavery context. Indeed, race also arguably underpinned differences between how post-1945 debates about the future of the OTs played out in Montserrat versus the white settler Falkland Islands.

Along with this racial coding came a range of material differentiations, from the mobility of various bodies (e.g., the possibility of migration to the UK) to the attribution of material 'viability' or 'unviability' to various territories with regard to independence. The latter - a paternalist discourse of sovereignty - seeks to define the minimum 'size' necessary for a polity to survive on its own, whether that size be territorial, economic, or demographic (on resilience, see Grove 2013). Of course, as we shall see the 'size' necessary also depends on the hypothesized shock that a polity must be able to endure without assistance. One early solution to the problem of the 'unviable' Caribbean island territories was to aggregate them into a more viable formation: the Federation of the 
West Indies (Taylor 2000). This Federation lasted only four years (1958-1962) before dissolution because of questions over the degree to which flows - of money, migrant bodies, and goods - ought to be enabled within the Federation (it lacked a customs union, for instance). In the wake of this deterritorialization, Montserrat opted in 1961 to remain a dependency of the UK, albeit one with increasing political autonomy and economic success (British budgetary aid ended in 1981 - see Clay et al., 1999). This economic success contributed to a sense of Montserrat as 'viable' and self-sustaining, as long as flows of tourists and agricultural exports continued.

However, the dynamism of the earth and its systems has worked to undercut the perceived viability of Montserrat. Indeed, it is impossible to explain the current relationship between Montserrat and the British Government without taking into account the agency of the earth (Barry 2013; Yusoff 2013; Squire 2016). The initial blow to viability came from the air: 'When Hurricane Hugo struck in late 1989, commitment to remaining a colony of Britain was strengthened as people saw the UK Government pour so much support and financial aid into the island and Montserratians worked alongside Royal Navy officers who came to help with the clean-up and rebuilding' (Skelton 2000: 108). The intense flows of capital, bodies, and support provided an affective context in which the bonds of colonialism could feel welcome. Still, by 1995 things had largely returned to pre-hurricane levels and the economy was 
in surplus. This was a positive affirmation of Montserrat's viability and resilience, albeit one dependent on latent colonial bonds that could be activated in times of need.

The second blow to viability came from the earth itself. On 25 June 1997 the Soufriere Hills volcano erupted, killing 19 people and burying Plymouth, the capital and only major settlement on the island, in ash. As a British Government commissioned report noted afterwards, 'With half the island in an exclusion zone... the continuing viability of the island for human habitation was in doubt... [with] the only settlement possibilities being confined to the northern third of the island' (Clay et al., 1999: 16). This event triggered the suspension of existing social and political structures both within the island, and between Montserrat and the UK. This already liminal polity entered into a heightened liminal phase. The eruption also unleashed a series of migrant flows, with roughly $90 \%$ of the pre-volcano population having to relocate at least once, and nearly two-thirds of the population fleeing the island entirely (ibid.). The seemingly permanent state of anxiety that afflicts the remaining islanders is the result of the scientific uncertainty surrounding the geology of the island's south (will the volcano blow again? When?). This affect of anxiety has been generative of creative economic activities in Montserrat, crystalizing around (for instance) new models of disaster tourism, but nothing that replaces the $20 \%$ of the GDP lost by the decline of traditional tourism (Gaudru 2014). 
The volcanic eruption was thus not only a geophysical event but also a political one. It literally reshaped the ground on which the Montserratians stood, and equally it reshaped Whitehall subjectivities: 'The main town, Plymouth, was buried in ash and lava, highlighting the UK government's contingent liability in a particularly visible way. With Montserrat, a "little known pink bit" [of the map] suddenly became highly visible, perhaps for the first time since the Falklands War' (Hintjens and Hodge 2012: 199). This 'contingent liability' primarily took the form of financial and material support; since 1997 DfID has provided $£ 324$ million in aid to Montserrat, or roughly half of the aid provided to all OTs.

Nevertheless, the response of the UK Government to the volcano received mixed reviews, as the political responsibilities were problematically divided between Her Majesty's Government and the Government of Montserrat, and between the FCO and DfID. As a former governor of Montserrat later wrote,

It seems to me that there was a case for the assumption of direct rule [by the Crown's Governor] - it is hard to imagine a more appropriate situation - but that, given Montserrat's 40 years of near independence it would not have been supported by the British Government, even where it might have produced more efficient decision making and perhaps saved lives. (Taylor 2000, 341, emphasis added) 
The paradox here - of a colonial power reluctant to wield executive power, and of a colony reiterating its continued dependence - indicates how much the agency of the volcano has materially reshaped the processes by which political subjectivities were emergent in the Eastern Caribbean. In short, the 'viability' of Montserrat had been decimated, and the subsequent relations between the UK and Montserrat would come to be defined by long-term dependency.

Given DfID's role in funding the infrastructure that is meant to produce 'selfsufficiency', it is not surprising that it maintains a paternal relationship with the Government of Montserrat. This diplomatic activity includes UK-based DfID staff visiting the island 'to negotiate Montserrat's budget and determine its progress towards meeting agreed goals,' (ICAI 2013: 3) and a Memorandum of Understanding (MoU) signed between the DfID and the Government of Montserrat in 2012 whereby, in order to gain a tranche of development funds for a new capital (Little Bay) and port (Carr's Bay) as well as improved land/sea access, the Government of Montserrat had to accept a swathe of investment, immigration and tax reforms (Memorandum 2012). Notably, these reforms undercut Montserratian autonomy by unleashing flows of money, migrant bodies, and goods: the very same flows that tore the Federation of the West Indies apart in 1962. This time, however, the politics of postcoloniality have been eclipsed by the politics of coloniality, with Montserrat reaching a tipping point between equilibria of viability and unviability. While DfID's role in auditing the books indicates both the 
political cost of dependency for Montserrat, and the on-going focus by both sides on the production of viability, the MoU and increased control from London recalls nothing so much as the Crown Colony period of the late-nineteenth century.

A range of post-1997 material flows - pyroclastic, capital, and migrant - have thus rendered Montserrat subordinate to DfID, and that geologic agency has reshaped the political subjectivities of all involved. Montserrat, once a model of Caribbean development whose leaders aspired to autonomy and perhaps independence, has been opened up to external intervention. The material existence of the MoU and its circulation between civil servants in Montserrat and London renders tangible the differentiation of particular spaces and the production of hierarchy within them over time. Moreover, whereas political ecology approaches have emphasized the roots of purportedly 'natural' disasters in human politics and economics, an assemblage approach highlights the ability of both human and non-human forces to affect policymakers' sensibilities and subjectivities around risk, resilience, and vulnerability.

While this account has emphasized the increasing subjection of the Montserratian people to the power of the volcano, and subsequently to DfID, it is nevertheless worth noting that Montserrat - like the Falkland Islands - has to go before the UN Decolonization Committee. In 2012 then-Premier Meade asked for Montserrat to be removed from the list of NSGTs, arguing - again, like the Falkland Islands - that the people of Montserrat had chosen this political subjectivity (Clegg 2013). While it is 
increasingly difficult to argue that Montserrat has any real choices in its current 'unviability', the ability to portray oneself (or be portrayed) in multiple states - as selfgoverning, or as a dependency - to different audiences is key to inhabiting a liminal subjectivity. While the trajectory of Montserrat has gone from Crown Colony to protoindependence and back again, it is clear that its liminality is both something its leaders can direct to its advantage with different audiences, but also a status shaped by the actions of the Lesser Antilles Volcanic Arc, as well as centuries of imperial politicaleconomy. An assemblage-oriented geopolitics must account for all these human and non-human forces, and understand how they render the ground on which politics rests and therefore the subjectivities and sensibilities of policy-makers - unstable.

\section{Conclusion}

In this paper we have brought together conceptual frameworks developed in fields not usually associated with diplomacy - cultural anthropology, cultural geography and science and technology studies (STS) - into dialogue with the increasingly diversified and dynamic diplomatic landscape. Specifically we have highlighted productive and as yet unexplored intersections between anthropological literature on liminality and the STS-inflected literature on assemblage, with its focus on materiality, tipping points and the processual nature of international life. We suggest that this intersection can offer a new and innovative approach to the study of diplomacy. Augmenting work in critical 
diplomacy studies that promotes a relational approach, the framing that we outline here brings to the fore the creative and entrepreneurial aspects of diplomatic practice, shifts attention to the role of materiality and non-human agency in diplomacy, highlights the insights that can be gained from shifting our attention to the perspective of liminal polities, and offers a novel perspective on questions of legitimacy in the field of diplomacy.

In working through the intersections between liminality and assemblage we have turned attention to the oft-overlooked diplomatic articulations of the British Overseas Territories. We have suggested that, existing somewhere between independent states and colonial dependencies, these are inherently liminal state-like assemblages that can take on several distinct formations. In other words they can present themselves (or be presented) as existing in multiple states at once (e.g., as either politically subordinate to the UK or as an independent diplomatic actor). The capacity to deploy material resources (e.g., diplomats, ballots, development aid) in ways that are productive of multiple political subjectivities enables the potential for creativity and the sense of unsettled-ness that the literature on liminality conveys, but does not explain. We have sought to do precisely this through three our vignettes.

Liminality and assemblage have thus together helped us to conceptualize a particular set of diplomatic relationships over time, but we suggest that our theoretical fusion can also inform a wider range of studies. For instance, STS is both where 
assemblage theory emerged and also a field that has problematized the relationship between micro-scaled practices (in this case OT diplomacy) and macro-scaled phenomena (such as the state, or the diplomatic system). However, the focus in STS has tended to be on specific technologies and the scientific knowledges that surround them. Here we have focused on diplomatic events in the OTs that demonstrate liminality, and sought to trace the materialities that shaped those events. This thus has the potential to extend the empirical gaze of STS scholarship and also put STS scholars into dialogue with the concept of liminality. Similarly, for anthropologists, bringing liminality into dialogue with assemblage foregrounds questions of materiality, tipping points and affect and has the potential both to reinvigorate work on liminality and forge connections with work in STS and human geography.

In political geography our conceptualisation provides a language for empirically tracing the event, in which various assemblages shift from one formation to another. Given the (relatively) flat ontology of assemblage theory, this liminal status can be experienced by assemblages 'small' (e.g., an OT representative in London) or 'large' (e.g., Iraqi 'sovereignty' taken away in 2003 and ceremonially restored in 2004). Indeed, liminality -as the inverse of resilience- may be understood as a characteristic of any assemblage that has the potential for rapid transformation, a characteristic that is of course dependent on the magnitude of the force that might be unleashed upon it in any given time. Following from our case studies, the autonomy of any polity - whether 
'unviable' like Montserrat or paternalist like the UK - is contingent on a range of geophysical, climatic and other forces as well as the traditional military, political, and economic concerns. Therefore, it is incumbent on scholars to focus on the events that are constantly re-making our world in ways both large and small.

\section{Acknowledgements}

We are immensely grateful to the London-based representatives of the British Overseas Territories who took time to meet with us, and to the editor and anonymous reviewers for their insightful critiques and comments on earlier drafts of this paper.

\section{References}

Adler-Nissen R Gad U P (2013). European Integration and Postcolonial Sovereignty

Games : The EU Overseas Countries and Territories. London: Routledge

Aldrich R and Connell J (1998). The Last Colonies. Cambridge: Cambridge University Press.

Anderson B and McFarlane C (2011) Assemblage and geography. Area 43(2): 124-127. Barry A (2013). Material Politics: Disputes Along the Pipeline. Chichester: John Wiley and Sons. 
Benwell M and Dodds K (2011). Argentine territorial nationalism revisited: The Malvinas/Falklands dispute and geographies of everyday nationalism. Political Geography 30(8): 441-449.

Bjola C and Holmes M (2015). Digital Diplomacy: theory and practice. London: Routledge.

Callon M (1986). Some Elements of a Sociology of Translation: Domestication of the Scallops and the Fishermen of St Brieuc Bay, in Power, Action and Belief: A New Sociology of Knowledge Ed J Law London: Routledge. pp 196-233

Clay E Barrow C Benson C Dempster J Kokelaar P Pillai N and Seaman J (1999). An Evaluation of HMG's Response to the Montserrat Volcanic Emergency, Volume 1. London: DfID.

Caspersen, N. (2015). "Degrees of legitimacy: Ensuring internal and external support in the absence of recognition." Geoforum 66: 184-192.

Clegg P (2009). Governing the UK Caribbean Overseas Territories: a two-way perspective, in Governance in the Non-independent Caribbean Eds P Clegg, E Pantojas-Garcia. Kingston: Ian Randles Publishers. pp 3-23

Clegg P (2013). The United Kingdom and its Caribbean Overseas Territories: Present Relations and Future Prospects. Caribbean Journal of International Relations and Diplomacy 1(2): 53-64. 
Clegg P and Gold P (2011). The UK Overseas Territories: a decade of progress and prosperity? Commonwealth \& Comparative Politics 49(1): 115-135.

Clegg P and Killingray D eds. (2012). The non-independent territories of the Caribbean and Pacific: Continuity or change? London: Institute of Commonwealth Studies, University of London

Constantinou C M (1996). On the Way to Diplomacy . Minneapolis: University of Minnesota Press.

Constantinou C and Der Derian J (2010). Sustainable Diplomacies. London: Palgrave Macmillan.

Cornago N (2010). On the Normalization of Sub-State Diplomacy. The Hague Journal of Diplomacy 5: 11-36

DeLanda M (2006). A new philosophy of society: assemblage theory and social complexity. London: Continuum.

Deleuze G and Guattari F (2001). A Thousand Plateaus. London: Continuum.

Der Derian J (1987). On Diplomacy: A Genealogy of Western Estrangement Oxford: Blackwell.

Dickson F (2014). The Internationalisation of Regions: Paradiplomacy or Multi-level Governance? Geography Compass 8: 689-700

Dittmer J (2014). Geopolitical assemblages and complexity. Progress in Human Geography 38: 385-401 
Dittmer J (2015). Everyday Diplomacy: UKUSA Intelligence Cooperation and Geopolitical Assemblages. Annals of the American Association of Geographers 105(3): 604-619.

Dittmer J (2016). Theorizing a More-than-Human Diplomacy: Assembling the British Foreign Office, 1839-1874. The Hague Journal of Diplomacy 11(1): 78-104.

Dittmer J and McConnell F Eds. (2016). Diplomatic Cultures and International Politics: Translations, Spaces and Alternatives. Abingdon: Routledge.

Dodds K (2002). Pink Ice: Britain and the South Atlantic Empire. London: I.B. Taurus. Dodds K (2016). Our seabed?: Argentina, the Falklands and the wider South Atlantic. Polar Record 52:1-6

Dodds K and Pinkerton A (2013). The Falkland Islands Referendum 2013. Polar Record 49(4): 413-416.

FCO (1999). Partnership for Progress and Prosperity: Britain and the Overseas Territories - A Modern Partnership. London: HMSO.

FCO (2012). The Overseas Territories: Security, Success and Sustainability. London: FCO.

Gaudru H (2014). Volcano Tourism: The effect of eruptions and disasters, in Volcanic Tourist Destinations Ed P Erfurt-Cooper. Heidelberg and London: Springer. pp 337-50. 
Grove K (2013). Hidden transcripts of resilience: power and politics in Jamaican disaster management. Resilience 1(3): 193-209.

Hintjens H and Hodge D (2012). The UK Caribbean Overseas Territories: governing unruliness amidst the extraterritorial EU. Commonwealth \& Comparative Politics 50(2): 190-225.

Hocking B Melissen J Riordan S and Sharp P (2012). Futures for Diplomacy: Integrative Diplomacy for the 21st Century. The Hague: Clingendael.

Horvath A (2009). Liminality and the unreal class of the image-making craft: An Essay on Political Alchemy. International Political Anthropology 2:51-73

Horvath A Thomassen B and Wydra H (2015). Breaking boundaries: varieties of liminality. Oxford: Berghan.

Keeling D (2013). A geopolitical perspective on Argentina's Malvinas/Falkland claims. Global Discourse 3(1): 158-165.

Hudson A (1998). Reshaping the regulatory landscape: border skirmishes around the Bahamas and Cayman offshore financial centres. Review of International Political Economy 5:534-564

ICAI (2013). DFID's Support to Capital Projects in Montserrat. London: ICAI Ingram A (2017). Geopolitical events and fascist machines: Trump, Brexit and the deterritorialisation of the West. Political Geography 57: 91-93 
Jeffrey A (2013). The Improvised State: Sovereignty, Performance and Agency in Dayton Bosnia. Oxford: Wiley.

Jeffrey, A., F. McConnell, et al. (2015). Understanding legitimacy: Perspectives from anomalous geopolitical spaces. Geoforum 66: 177-183.

Jones A and Clark J (2015). Mundane diplomacies for the practice of European geopolitics. Geoforum 62:1-12

Keating M (1999). Regions and International Affairs: Motives, Opportunities and Strategies. in Paradiplomacy in Action: The Foreign Relations of Subnational Governments Eds F Aldecoa and M Keating. Portland: Frank Cass pp 1-1

Kuus M (2014). Geopolitics and Expertise: Knowledge and Authority in European Diplomacy. London: Wiley.

Lambert D (2005). 'As Solid as the Rock'? Place, Belonging and the Local Appropriation of Imperial Discourse in Gibraltar. Transactions of the Institute of British Geographers 30:206-220

Latour B (2005). Reassembling the Social: An Introduction to Actor-Network-Theory. Oxford: Oxford University Press.

Legg S (2009). Of scales, networks and assemblages: the League of Nations apparatus and the scalar sovereignty of the Government of India. Transactions of the Institute of British Geographers 34:234-253 
Mälksoo M (2012). The challenge of liminality for International Relations theory. Review of International Studies 38(2): 481-494.

McConnell F (2016). Rehearsing the State: The Political Practices of the Tibetan Government-in-Exile. Oxford: Wiley.

McConnell F (2017). Liminal Geopolitics: the subjectivity and spatiality of diplomacy at the margins. Transactions of the Institute of British Geographers 42(1): 139152

Memorandum of Understanding Between the Government of Montserrat (GoM) and the UK Department for International Development (DfID) (2012) Available at http://www.gov.ms/wp-content/uploads/2012/05/MOU-Reforms.pdf (last accessed 25 October 2016).

Navaro-Yashin Y (2003). 'Life is Dead Here': Sensing the Political in 'No Man's Land' Anthropological Theory 3:107-125

Neumann I B (2002). Returning Practice to the Linguistic Turn: The Case of Diplomacy. Millennium: Journal of International Studies 31: 627-651

Norton A (1988). Reflections on political identity. Baltimore: The Johns Hopkins University Press.

Oostindie G and Klinkers I (2003). Decolonising the Caribbean: Dutch Policies in Comparative Perspective. Amsterdam: Amsterdam University Press. 
Page S and Dittmer J (2015). Assembling Political Parties. Geography Compass 9:25161

Pinkerton A and Benwell M (2014). Rethinking popular geopolitics in the Falklands/Malvinas sovereignty dispute: Creative diplomacy and citizen statecraft. Political Geography 38: 12-22.

Protevi J (2009) Political Affect: Connecting the social and the somatic. Minneapolis: University of Minnesota Press.

Rumelili B (2003). Liminality and Perpetuation of Conflicts: Turkish-Greek Relations in the context of community building by the EU. European Journal of International Relations 9(2): 213-248.

Sending O J Pouliot V and Neumann I (2011). The future of diplomacy: Changing practices, evolving relationships. International Journal $66: 527-42$

Sharp J (2013). Geopolitics at the margins? Reconsidering genealogies of critical geopolitics. Political Geography 37:20-29

Shaw I (2012). Towards an evental geography. Progress in Human Geography 36:61327

Skelton T (2000). Political Uncertainties and Natural Disasters: Montserratian identity and colonial status. Interventions: International Journal of Postcolonial Studies 2(1): 103-117. 
Soja E (1996). Thirdspace: Journeys to Los Angeles and other Real-and-imagined Places. Oxford: Blackwells.

Squire R (2016). Rock, water, air and fire: Foregrounding the elements in the GibraltarSpain dispute. Environment and Planning D: Society and Space 34(3): 545-563. Special Committee on Decolonization Approves Text Reiterating Need for Negotiated Settlement of Falkland Islands (Malvinas) Question. 20 June 2013. GA/COL/3257. Available at: http://www.un.org/press/en/2013/gacol3257.doc.htm Szakolczai A (2015). Liminality and Experience: Structuring transitory situations and transformative events. in Breaking boundaries: varieties of liminality Eds A Horvath B Thomassen and H Wydra. Oxford: Berghan pp 11-38 Taylor D (2000). British Colonial Policy in the Caribbean: The insoluble dilemma - the case of Montserrat. The Round Table 355: 337-344.

Thomassen B (2014). Liminality and the Modern: Living Through the In-Between. Farnham: Ashgate.

Thomassen B (2015). Thinking with Liminality: To the Boundaries of an Anthropological Concept. in Breaking boundaries: varieties of liminality Eds A Horvath B Thomassen and H Wydra. Oxford: Berghan pp 39-60 Turner V (1969). The Ritual Process: Structure and Anti-structure. Chicago: Aldine. 
Turner V (1974). Dramas, Fields, and Metaphors: Symolic Action in Human Society. Ithaca, NY: Cornell University Press.

van Gennep A (1960 [1909]). The rites of passage. London: Routledge.

Walker R B J (2003). Polis, Cosmopolis, Politics. Alternatives 28:267-286

Weber C (1998). Performative States. Millennium: Journal of International Studies $27: 78-95$

Yanık L K (2011). Constructing Turkish “exceptionalism”: Discourses of liminality and hybridity in post-Cold War Turkish foreign policy. Political Geography 30(2): 80-89.

Yusof, K (2016). Geologic Life: Prehistory, climate, futures in the Anthropocene. Environment and Planning D 31: 779-795. 